УДК 633.15: 631.527.5.003.13: 006.83

(C) 2015

Баган А. В., кандидат сільськогосподарських наук

Полтавська державна аграрна академія

\title{
ФОРМУВАННЯ ПРОДУКТИВНОСТІ ТА ЯКОСТІ ЗЕРНА ГІБРИДІВ КУКУРУДЗИ ЗАЛЕЖНО ВІД ПОПЕРЕДНИКА
}

\section{Рецензент - доктор сільськогосподарських наук, професор Г. П. Жемела}

Досліджено елементи продуктивності, рівень урожайності та показники якості зерна гібридів кукурудзи ТОВ «Монсанто» залежно від попередника у виробничих умовах Полтавської області. Вивчено вплив пшениці озимої та гороху на формування маси качана, маси зерна з качана, показник урожайності, маси 1000 зерен та вміст білка у досліджуваних гібридів. Виділено кращчий попередник - горох та рекомендовано для вирощування кращі гібриди кукурудзи за господарсько-иінними ознаками.

Ключові слова: кукурудза, гібрид, попередник, маса качана, маса зерна з качана, маса 1000 зерен, вміст білка, урожайність.

Постановка проблеми. На сучасному етапі перед виробниками сільськогосподарської продукції в Україні стоїть завдання значного підвищення продуктивності кукурудзи для потреб народного господарства. Вирішити це питання можливо за умови застосування високоурожайних гібридів, передових енергозберігаючих технологій, насіння високої якості тощо.

Кліматичні умови та грунти України повністю відповідають біологічним потребам кукурудзи. За умов застосування сучасних технологій вирощування та високопродуктивних гібридів, урожайність зерна може сягати 80-100 ц/га, що зробить дану культуру провідною за рентабельністю в Україні $[1,4]$. Тому актуальним залишається питання вивчення продуктивності та якості зерна гібридів кукурудзи залежно від попередника в умовах Полтавської області.

Аналіз основних досліджень і публікацій, в яких започатковано розв'язання проблеми. У селекції кукурудзи на підвищення врожаю зерна велике значення має сприятливе сполучення таких елементів продуктивності, як маса качана i маса зерна $з$ качана, кількість рядів зерен на качані і кількість зерен у ряду, вихід зерна з качана. Один з резервів підвищення врожаю зерна збільшення числа качанів на рослині. Результати польових досліджень, проведених на дрібноділянкових польових дослідах у зоні Центрального Лісостепу в 2009-2011 рр., свідчать про те, що збільшення густоти стояння рослин від 60 до 80-
100 тис./га зумовлює певні морфологічні зміни рослини в цілому та качана зокрема, які впливають на її індивідуальну продуктивність [5].

Основний напрям селекції кукурудзи на якість зерна - створення гібридів 3 покращеною якістю білка, збалансованого за амінокислотним складом. Відомо, що кількість білка в зерні кукурудзи становить 10-13\%. Створення високобілкових (16-20\%) гібридів кукурудзи залишається одним із важливих завдань для вітчизняних селекціонерів [2-4].

Мета досліджень - встановлення рівня формування елементів продуктивності, урожайності та показників якості зерна гібридів кукурудзи залежно від попередника в умовах Полтавської області.

Завдання під час проведення досліджень:

- визначити рівень формування елементів продуктивності (маси качана та маси зерна 3 качана), урожайності та показників якості зерна (маси 1000 зерен та вмісту білка) у гібридів кукурудзи залежно від попередника (гороху і пшениці озимої);

- виділити цінні джерела за досліджуваними ознаками для вирощування кукурудзи у виробничих умовах Полтавської області.

Матеріали і методика досліджень. Матеріалом для досліджень були чотири гібриди кукурудзи ТОВ «Монсанто» ДКС 3871, ДК 291, PR 39 A 50, PR 39 R 20. Польові дослідження проводили протягом 2012-2014 pр. у виробничих умовах ФГ «Сакура - С» Козельщинського району Полтавської області.

Елементи продуктивності та показники якості зерна визначали за загальноприйнятою методикою в лабораторії якості зерна Полтавської державної аграрної академії.

Результати досліджень. За роки досліджень маса качана у гібридів кукурудзи залежно від попередника відповідно становила: після пшениці озимої у 2012 році $179,6-217,3$ г, у 2013 році 204,2-268,0 г, у 2014 році 205,3-254,8 г; після гороху дана ознака була більшою - у 2012 році 197,5-231,4 г, у 2013 році 220,2-281,0 г, у 2014 році 206,5-270,4 г (табл. 1). 
СІЛЬСЬКЕ ГОСПОДАРСТВО. РОСЛИННИЦТВО

\section{1. Елементи продуктивності у гібридів кукурудзи}

\begin{tabular}{|c|c|c|c|c|c|c|c|c|}
\hline \multirow{3}{*}{ Гібрид } & \multicolumn{4}{|c|}{ Маса качана, г } & \multicolumn{4}{|c|}{ Маса зерна з качана, г } \\
\hline & \multicolumn{4}{|c|}{ Роки } & \multicolumn{4}{|c|}{ Роки } \\
\hline & 2012 & 2013 & 2014 & Середнє & 2012 & 2013 & 2014 & Середнє \\
\hline \multicolumn{9}{|c|}{ Попередник - пшениця озима } \\
\hline ДКС 3871 & 182,3 & 268,0 & 254,8 & 235,0 & 148,7 & 218,7 & 206,9 & 191,4 \\
\hline ДК 291 & 195,4 & 204,2 & 205,3 & 201,6 & 176,4 & 182,4 & 180,7 & 179,8 \\
\hline PR 39 A 50 & 179,6 & 229,2 & 219,1 & 209,3 & 155,7 & 195,0 & 182,5 & 177,7 \\
\hline PR 39 R 20 & 217,3 & 266,3 & 253,2 & 245,6 & 190,0 & 224,8 & 219,2 & 211,3 \\
\hline \multicolumn{9}{|c|}{ Попередник - горох } \\
\hline ДКС 3871 & 197,5 & 280,0 & 258,4 & 245,3 & 156,6 & 239,0 & 200,5 & 198,7 \\
\hline ДК 291 & 205,6 & 220,2 & 206,5 & 210,8 & 181,0 & 202,6 & 194,8 & 192,8 \\
\hline PR 39 A 50 & 198,1 & 241,4 & 220,8 & 220,1 & 160,4 & 207,7 & 186,4 & 184,8 \\
\hline PR 39 R 20 & 231,4 & 281,0 & 270,4 & 260,9 & 204,9 & 240,2 & 235,4 & 226,8 \\
\hline
\end{tabular}

За середніми даними найбільшою масою качана характеризувався гібрид PR 39 R 20, у якого даний показник, залежно від попередника, становив 245,6 г (після пшениці озимої) і 260,9 г (після гороху).

Ознака маси зерна 3 качана залежно від попередника у гібридів кукурудзи протягом 20122014 років варіювала таким чином: після пшениці озимої - у 2012 році 148,7-190,0 г, у 2013 році 182,4-224,8 г, у 2014 році 180,7-219,2 г; після гороху - у 2012 році $160,4-204,9$ г, у 2013 році 202,6-240,2 г, у 2014 році $186,4-235,5$ г.

Аналогічно масі качана, показник маси зерна 3 качана залежно від попередника найбільшим був у гібрида PR 39 R 20 і відповідно становив 211,3 г (після пшениці озимої) і 226,8 г (після гороху).

У середньому за роки досліджень урожайність кукурудзи залежно від попередника більшою була у гібрида PR 39 R 20 і становила 10,0911,43 т/га. Найменша урожайність спостерігалася у гібрида PR 39 А 50-8,30-9,20 т/га.

2012 рік характеризувався найменшим значенням даного показника - 6,91-8,82 т/га.

Так, після попередника пшениця озима найбільшу урожайність мав гібрид PR 39 R 20 (фактор А) $-8,37$ т/га, який суттєво перевищував за даним показником гібрид ДК 291 (6,91 т/га).

Після попередника горох спостерігалася аналогічна ситуація: гібрид PR 39 R 20 характеризувався суттєво більшим значенням даної ознаки $(8,82$ т/га), порівняно із гібридом PR 39 А 50 $(7,47 \mathrm{~T} /$ га).
За попередниками (фактор В) у гібридів ДКС 3871 і ДК 291 урожайність після гороху $(8,01$ т/га і 7,73 т/га відповідно) була істотно більшою, ніж після пшениці озимої (7,23 т/га і 6,91 т/га відповідно).

У 2013 році урожайність кукурудзи була найбільшою - 9,89-13,01 т/га.

Гібрид PR 39 R 20 після пшениці озимої мав найбільшу урожайність $(12,45$ т/га), за якою істотно перевищував гібриди ДК 291 (9,89 т/га) і PR 39 A 50 (10,08 т/га).

Після гороху гібрид PR 39 R 20 також характеризувався найбільшою урожайністю (13,01 т/га), яка була істотно більшою, порівняно 3 гібридом ДК 291 (10,32 т/га).

За попередниками гібриди PR 39 A 50 i PR 39 R 20 після гороху мали суттєво більшу урожайність (10,78 т/га і 13,01 т/га відповідно), порівняно з урожайністю після пшениці озимої.

2014 рік за урожайністю кукурудзи дещо поступався минулому - 7,75-12,45 т/га.

Гібрид PR 39 R 20 після пшениці озимої характеризувався найбільшою урожайністю $(9,45$ т/га), за якою суттєво перевищував гібрид PR 39 А 50 (7,75 т/га).

Аналогічно, після гороху у гібриду PR 39 R 20 спостерігалося найбільше значення даної ознаки $(12,45$ т/га), яка суттєво перевищувала за досліджуваним показником інші гібриди кукурудзи (табл. 2). 
СІЛЬСЬКЕ ГОСПОДАРСТВО. РОСЛИННИЦТВО

\section{2. Урожайність гібридів кукурудзи залежно від попередника, $\mathrm{m} / 2 a$}

\begin{tabular}{|c|c|c|c|c|}
\hline \multirow{2}{*}{$\begin{array}{c}\text { Гібрид } \\
\text { (фактор А) }\end{array}$} & \multicolumn{4}{|c|}{ Роки } \\
\hline & 2012 & 2013 & 2014 & Середнє \\
\hline \multicolumn{5}{|c|}{ Попередник - пшениця озима (фактор В) } \\
\hline ДКС 3871 & 7,23 & 10,81 & 8,90 & 8,98 \\
\hline ДК 291 & 6,91 & 9,89 & 8,19 & 8,33 \\
\hline PR 39 A 50 & 7,12 & 10,08 & 7,75 & 8,30 \\
\hline PR 39 R 20 & 8,37 & 12,45 & 9,45 & 10,09 \\
\hline \multicolumn{5}{|c|}{ Попередник - горох (фактор В) } \\
\hline ДКС 3871 & 8,01 & 11,05 & 10,07 & 9,71 \\
\hline ДК 291 & 7,73 & 10,32 & 9,91 & 9,32 \\
\hline PR 39 A 50 & 7,47 & 10,78 & 9,22 & 9,20 \\
\hline PR 39 R 20 & 8,82 & 13,01 & 12,45 & 11,43 \\
\hline \multicolumn{5}{|c|}{ Середнє по досліду = 9,32 } \\
\hline $\begin{array}{c}\mathrm{HIP}_{05} \\
\text { фактор (A) }\end{array}$ & 1,32 & 2,34 & 1,67 & \\
\hline $\begin{array}{c}\mathrm{HIP}_{05} \\
\text { фактор (B) }\end{array}$ & 0,53 & 0,45 & 1,51 & \\
\hline $\begin{array}{c}\mathrm{HIP}_{05} \text { взаємодія } \\
\text { фактор (AB) }\end{array}$ & 2,03 & 2,09 & 1,70 & \\
\hline
\end{tabular}

3. Показники якості зерна у гібридів кукурудзи

\begin{tabular}{|c|c|c|c|c|c|c|c|c|}
\hline \multirow{3}{*}{ Гібрид } & \multicolumn{4}{|c|}{ Мaca 1000 зерен, г } & \multicolumn{4}{|c|}{ Вміст білка, \% } \\
\hline & \multicolumn{4}{|c|}{ Роки } & \multicolumn{4}{|c|}{ Роки } \\
\hline & 2012 & 2013 & 2014 & Середнє & 2012 & 2013 & 2014 & Середнє \\
\hline \multicolumn{9}{|c|}{ Попередник - пшениця озима } \\
\hline ДКС 3871 & 348,0 & 360,3 & 352,4 & 353,6 & 10,1 & 11,0 & 11,8 & 10,9 \\
\hline ДК 291 & 250,6 & 259,8 & 250,8 & 253,7 & 10,5 & 11,3 & 11,5 & 11,1 \\
\hline PR 39 A 50 & 300,6 & 304,7 & 297,5 & 300,9 & 9,8 & 10,6 & 10,8 & 10,4 \\
\hline PR 39 R 20 & 332,1 & 347,1 & 336,4 & 338,5 & 9,8 & 10,8 & 10,3 & 10,3 \\
\hline \multicolumn{9}{|c|}{ Попередник - горох } \\
\hline ДКС 3871 & 360,1 & 381,9 & 385,5 & 375,8 & 10,9 & 12,0 & 12,5 & 11,8 \\
\hline ДК 291 & 270,4 & 281,2 & 275,5 & 275,7 & 11,3 & 12,8 & 12,6 & 12,2 \\
\hline PR 39 A 50 & 312,5 & 317,4 & 310,8 & 313,5 & 10,5 & 11,2 & 11,5 & 11,1 \\
\hline PR 39 R 20 & 352,8 & 364,1 & 358,5 & 358,4 & 10,3 & 11,3 & 11,7 & 11,1 \\
\hline
\end{tabular}

За попередниками гібриди ДК 291 i PR 39 R 20 характеризувалися істотно більшою урожайністю після гороху (9,91 т/га і 12,45 т/га відповідно), порівняно 3 урожайністю після пшениці озимої.

За середніми даними найбільшою урожайністю характеризувався гібрид кукурудзи PR 39 R 20 після попередника - горох (понад 11,0 т/га).

Показник маси 1000 зерен у гібридів кукурудзи за роки досліджень залежно від попередника відповідно становив: після пшениці озимої - у 2012 році $250,6-348,0$ г, у 2013 році $259,8-360,3$ г, у 2014 році $250,8-352,4$ г; після гороху був більшим - у 2012 році 270,4-360,1 г, у 2013 році 
281,2-381,9 г, у 2014 році 275,5-385,5 г (табл. 3).

Найбільшою масою 1000 зерен характеризувався гібрид ДКС 3871, у якого середнє значення даної ознаки становило 353,6 г (після пшениці озимої) і 375,8 г (після гороху).

Вміст білка у досліджуваних гібридів залежно від попередника варіював у таких межах: після пшениці озимої - у 2012 році 9,8-10,5\%, у 2013 році $10,6-11,3 \%$, у 2014 році $10,3-11,8 \%$; після гороху - у 2012 році $10,3-11,3 \%$, у 2013 році $11,2-12,8 \%$, у 2014 році $11,5-12,6 \%$.

За вмістом білка можна виділити гібрид куку-

\section{БІБЛІОГРАФІЯ}

1. Агафонов Н. М. Сроки посева, густота растений и продуктивность кукурузы / Н. М. Агафонов // Кукуруза и сорго. - 1996. - №2. - С. 7-8.

2. Домашнев П. П. Селекция кукурузы / П. П. Домашнев, Б. В. Дзюбецкий, В. И. Костюченко. М. : Агропромиздат, 1992. - 207 с.

3. Козубенко Л. В. Генетико-селекционные аспекты гетерозисной селекции кукурузы / Л. В. Козубенко, Н. М. Чупиков, Т. П. Камышан // Труды рудзи ДК 291 - 11,1 \% (після пшениці озимої) i $12,2 \%$ (після гороху).

\section{Висновки:}

1. За результатами досліджень елементів продуктивності, рівня урожайності та показників якості зерна у гібридів кукурудзи можна виділити кращий попередник - горох.

2. Гібрид PR 39 R 20 відмічено за масою качана, масою зерна $з$ качана та рівнем урожайності.

3. Гібрид ДКС 3871 характеризувався найбільшою масою 1000 зерен.

4. Гібрид ДК 291 виділено вмістом білка.

по фундаментальной и прикладной генетике. Х. : Штрих, 2001. - С. 183-196.

4. Коиюбан А. И. Предшественники и урожайность / А. И. Коцюбан // Кукуруза и сорго. 1990. - №1. - С. 17-19.

5. Соколов В. М. Селекція кукурудзи в США / В. М. Соколов, С. И. Мустяца // Кукуруза и сорго. - 1986. - №4. - С. 17-19. 